\title{
ANALISIS POTENSI PAJAK DAERAH DALAM PENINGKATAN PENDAPATAN ASLI DAERAH DI KOTA BITUNG
}

\author{
Gebriany Pirade Wenur, Herman Karamoy, Jessy Warongan \\ (email: gebrianyw@yahoo.com)
}

\begin{abstract}
Economic development requires government and the community to develop and explore the potentials of the region to supporting the better economy in the future. Local Tax is one of regional revenues that has an important role in supporting the implementation of regional development of Bitung. High earnings of local taxes will increase revenue (PAD) so the local government are expected to explore the revenue sources (PAD) in improving Local Revenue $(P A D)$ as to reduce dependence on the central government. This study is aimed to quantify and determine the potential of local taxes in the realization of the projected increase regional revenue in Bitung City. This research uses qualitative method with descriptive approach. Based on research and survey, Bitung City has unexplored local taxes potential by the local government (DIPENDA) to be explore. In 2016 to 2020 local taxes potential revenue has been projected to rising of 25 percent.
\end{abstract}

Keywords: Potential, Local Taxes, Local Revenue (PAD)

\section{PENDAHULUAN}

Pembangunan ekonomi saat ini menuntut pemerintah maupun masyarakat untuk mengembangkan dan memanfaatkan potensi-potensi yang dimiliki oleh suatu daerah dalam rangka menunjang perekonomian kearah yang lebih baik. Pelaksanaan otonomi daerah yang dititikberatkan pada kabupaten/kota dimulai dengan adanya penyerahan sejumlah kewenangan atau urusan dari pemerintah pusat ke pemerintah daerah yang bersangkutan. Dengan demikian guna mewujudkan penyelengaraan otonomi daerah yang bertanggung jawab untuk mengatur dan mengurus sendiri suatu daerah, perlu dilakukan perluasan objek pajak daerah dan retribusi daerah dan pemberian diskresi dalam penetapan tarif serta kebijakan pajak daerah dan retribusi daerah dilaksanakan berdasarkan prinsip demokrasi, pemerataan dan keadilan, peran serta masyarakat dan akuntabilitas dengan memperhatikan potensi daerah.

Kota Bitung merupakan salah satu Kota di Provinsi Sulawesi Utara yang merupakan Kota Pelabuhan Industri terbesar di Sulawesi serta termasuk kota pelabuhan terkemuka di Indonesia bagi pertumbuhan ekonomi yang sangat berperan dalam menunjang kegiatan perekonomian dan pembangunan di Sulawesi Utara, sehingga memiliki berbagai macam potensi - potensi yang berasal dari jenis pajak daerah yang harus digali guna menunjang pembangunan daerah. Potensi pajak berkaitan langsung dengan aktivitas ekonomi sektoral dan sistem serta kemampuan aparatur pemerintah daerah untuk menggali sumber-sumber pajak potensial yang dapat dijadikan sebagai basis utama Pendapatan Asli Daerah (PAD) di Kota Bitung. Banyaknya kebutuhan daerah dapat dibiayai oleh Pendapatan Asli Daerah (PAD), maka semakin tinggi tingkat kualitas otonomi daerah dan semakin mandiri dalam bidang keuangan daerahnya. Berdasarkan uraian pada latar belakang di atas maka yang jadi masalah dalam penelitian ini yaitu: Bagaimana potensi pajak daerah untuk proyeksi Pendapatan Asli Daerah (PAD) di Kota Bitung. 


\section{TINJAUAN PUSTAKA \\ Peacock dan Wiseman}

Peacock dan Wiseman mendasarkannya pada suatu analisis dialektika penerimaanpengeluaran pemerintah. Pemerintah selalu berusaha memperbesar pengeluarannya dengan mengandalkan penerimaan dari pajak. Padahal masyarakat tidak menyukai pembayaran pajak yang kian besar. Mengacu pada teori pemungutan suara (voting), mereka berpendapat bahwa masyarakat mempunyai batas toleransi pajak, yakni suatu tingkat dimana masyarakat dapat memahami besarnya pungutan pajak yang dibutuhkan oleh pemerintah untuk membiayai pengeluaran-pengeluarannya. Tingkat toleransi pajak ini merupakan kendala yang membatasi pemerintah untuk menaikkan pungutan pajak secara tidak semena-mena atau sewenang-wenang. (Mangkoesoebroto, 2001). Teori Peacock dan Wiseman Perkembangan ekonomi menyebabkan pemungutan pajak yang semakin meningkat walaupun tarif pajak tidak berubah dan meningkatnya penerimaan pajak menyebabkan pengeluaran pemerintah juga semakin meningkat. Oleh karena itu, dalam keadaan normal, meningkatnya GDP menyebabkan penerimaan pemerintah yang semakin besar, begitu juga dengan pengeluaran pemerintah menjadi semakin besar. (Sumual, 2016).

\section{Teori Pertumbuhan Ekonomi}

Pertumbuhan ekonomi merupakan salah satu ciri pokok dalam proses pembangunan, hal ini diperlukan hubungan dengan kenyataan adanya pertambahan penduduk. Bertambahnya penduduk dengan sendirinya menambah kebutuhan pangan, sandang dan pemukiman, pendidikan dan pelayanan kesehatan. Hubungan antara Pendapatan Asli Daerah dan Pertumbuhan Ekonomi yaitu Pendapatan Asli Daerah (PAD) Merupakan sumber pembelanjaan daerah, jika Pendapatan Asli Daerah (PAD) meningkat maka dana yang dimiliki oleh pemerintah daerah akan lebih tinggi dan tingkat kemandirian daerah akan meningkat pula, sehingga pemerintah daerah akan berinisiatif untuk lebih menggali potensi - potensi daerah dan meningkatkan pertumbuhan ekonomi. Pertumbuhan Pendapatan Asli Daerah (PAD) secara berkelanjutan akan menyebabkan peningkatan pertumbuhan ekonomi daerah tersebut. Peningkatan Pendapatan Asli Daerah berdampak pada perekonomian daerah. Oleh karena itu daerah tidak akan berhasil bila daerah tidak mengalami pertumbuhan ekonomi yang berarti meskipun terjadi peningkatan Penerimaan Pendapatan Asli Daerah (PAD).

\section{Pendapatan Asli Daerah}

Menurut Undang-Undang Nomor 28 Tahun 2009 tentang Pajak Daerah dan Retribusi Daerah, dinyatakan bahwa Pendapatan Asli Daerah (PAD) adalah sumber keuangan daerah yang digali dari wilayah daerah yang bersangkutan yang terdiri dari hasil pajak daerah, hasil retribusi daerah, hasil pengelolaan kekayaan daerah yang dipisahkan dan lain-lain pendapatan asli daerah yang sah. Pendapatan daerah terdiri dari :

1. Hasil Pajak Daerah;

2. Hasil Retribusi Daerah;

3. Hasil perusahaan milik daerah dan hasil pengelolaan kekayaan daerah yang dipisahkan;

4. Lain-lain pendapatan asli daerah lainnya yang sah.

\section{Definisi Pajak}

Pajak adalah iuran kepada negara (yang dapat dipaksakan) yang terutang oleh yang wajib membayarnya menurut peraturan-peraturan, dengan tidak mendapat prestasi kembali, yang 
langsung dapat ditunjuk, dan yang gunanya adalah untuk membiayai pengeluaran-pengeluaran umum berhubung tugas negara untuk menyelenggarakan pemerintahan. (Adriani dalam buku Sumarsan, 2013 : 3). Dari definisi tersebut, dapat disimpulkan bahwa pajak memiliki unsurunsur : (1) iuran dari rakyat kepada negara, yang berhak memungut pajak hanyalah negara. Iuran tersebut berupa uang (bukan barang); (2) berdasarkan undang-undang, pajak dipungut berdasarkan atau dengan kekuatan undang-undang serta aturan pelaksanaannya; (3) tanpa jasa timbal atau kotraprestasi dari negara yang secara langsung dapat ditunjuk. Dalam pembayaran pajak tidak dapat ditunjukkan adanya kontraprestasi individual oleh pemerintah; (4) digunakan untuk membiayai rumah tangga negara, yakni pengeluaran - pengeluaran yang bermanfaat bagi masyarakat luas.

\section{Pajak Daerah}

Pajak Daerah adalah iuran wajib yang dilakukan oleh orang pribadi atau badan kepada daerah tanpa imbalan langsung yang seimbang, yang dapat dipaksakan berdasarkan peraturan perundang-undangan yang berlaku, yang digunakan untuk membiayai penyelenggaraan pemerintahan daerah dan pembangunan daerah, (Mardiasmo, 2009 : 12).

\section{Potensi Penerimaan Pajak}

Potensi pajak sangat menentukan besarnya pajak daerah yang dapat dipungut, dengan demikian besarnya potensi pajak perlu diketahui untuk menetapkan besarnya target penerimaan pajak pada suatu periode. Merupakan hasil temuan pendataan di lapangan yang berkaitan jumlah serta frekuensi obyek pajak yang kemudian dikalikan dengan tarif dasar pajak. (Mardiasmo dan Makhfatih). Potensi pajak didefinisikan sebagai rasio pajak yang akan terjadi jika ekonomi menggunakan semua sumber daya dan kemampuan untuk mengumpulkan semua yang diperoleh pendapatan pajak dari hasil yang diberikan daerah tersebut. (Alfirman, 2003:9)

\section{METODE PENELITIAN}

Penelitian ini dilaksanakan pada Pemerintah Daerah Kota Bitung Provinsi Sulawesi Utara. Penelitian ini dilaksanakan pada Dinas Pendapatan Daerah Kota Bitung. Waktu penelitian dilakukan selama dua bulan pada bulan Mei sampai dengan bulan Juli 2016.

\section{Analisis Data}

\section{Analisis Komparatif}

Untuk mengukur rasio penerimaan pajak daerah dengan rumus sebagai berikut: (Mahsun, 2009 : 153)

Rasio Penerimaan Pajak Daerah terhadap PAD $=-\times 100 \%$

\section{Analisis Matriks Pertumbuhan dan Kontribusi}

a. Untuk mengetahui tingkat pertumbuhan masing - masing pajak atau jenis pajak daerah di gunakan rumus:

$$
\mathrm{gXi}=
$$

b. Untuk mengetahui kontribusi masing - masing pajak atau jenis pajak daerah digunakan rumus:

$$
\mathrm{wXi}=-
$$




\section{Analisis Potensi Pajak Daerah}

a. Pajak Hotel

Perhitungan potensi pajak hotel menggunakan rumus sebagai berikut: (Jamli dan Rahayu dalam Komalig, 2014)

Keterangan :

$$
\begin{gathered}
\mathrm{PH}=\mathrm{Jhtl} \times \mathrm{Rth} \times \mathrm{RJk} \times \mathrm{Jh} \\
\text { NPPH }=\text { PH } \times \text { Tp }
\end{gathered}
$$

$\mathrm{PH} \quad=$ Pendapatan Hotel (Rupiah)

NPPH = Nilai Potensi Pajak Hotel (Rupiah)

Jhtl = Jumlah Hotel (Unit) Rth = Rata-Rata Pengeluaran Tamu (Rupiah/Unit)

RJk = Rata-rata Jumlah Kamar Terhuni (Unit/Hari) Jh = Jumlah Hari (hari)

$\mathrm{Tp} \quad=$ Tarif Pajak $(\%)$

b. Pajak Restoran

Perhitungan potensi pajak restoran menggunakan rumus sebagai berikut: (Jamli dan Rahayu dalam Komalig, 2014)

$$
\begin{gathered}
P R=(J R \times R t \times R p t \times J h) \\
N P P R=P R \times T p
\end{gathered}
$$

Keterangan :

PR = Pendapatan Restoran (Rupiah)

NPPR = Nilai Potensi Pajak Restoran (Rupiah)

$\mathrm{JR} \quad=$ Jumlah Restoran (Unit)

Rt = Rata-rata tamu yang datang (Orang/hari)

$\mathrm{Tp} \quad=$ Tarif Pajak $(\%)$

Rpt = Rata-rata pembayaran per tamu (Rupiah/orang)

Jh = Jumlah hari (hari)

c. Pajak Hiburan

Perhitungan potensi pajak hiburan menggunakan rumus menurut (Jamli dan Rahayu dalam Komalig 2014).

Keterangan :

$$
\begin{gathered}
\mathrm{PHb}=\mathrm{JHb} \times \mathrm{Rt} \times \mathrm{Rpt} \\
\mathrm{NPPHb}=\mathrm{PHb} \times \mathrm{Tp}
\end{gathered}
$$

$\mathrm{PHb}=$ Pendapatan Hiburan (Rupiah)

NPPH = Nilai Potensi Pajak Hiburan (Rupiah)

$\mathrm{JHb}=$ Jumlah Hiburan (Unit)

Rt = Rata-rata tamu yang datang (Orang/tahun)

Rpt = Rata-rata pembayaran per tamu (Rupiah/tahun/orang)

Tp = Tarif Pajak (\%)

d. Pajak Reklame

Perhitungan potensi pajak Reklame menggunakan rumus menurut (Jamli dan Rahayu dalam Komalig 2014).

Keterangan :

$$
\begin{gathered}
\text { PRk }=\text { JR } \times \text { Rt } \times \text { Rpt } \times \text { Jh } \\
\text { NPPRk }=\text { PR } \times \text { Tp }
\end{gathered}
$$

PRk = Pendapatan Reklame (Rupiah) 
NPPRk = Nilai Potensi Pajak Reklame (Rupiah)

$\mathrm{Tp} \quad=$ Tarif Pajak (\%)

JR = Jumlah reklame yang terpasang selama satu tahun (Unit)

Rpt = Rata-rata pembayaran per reklame (Rupiah/unit)

e. Pajak Mineral Bukan Logam dan Batuan

Perhitungan potensi pajak mineral bukan logam dan batuan menggunakan rumus yang digunakan oleh pemerintah Kota Bitung berdasarkan peraturan walikota Nomor 1 Tahun 2013 tentang petunjuk pelaksanaan Pajak Mineral Bukan Logam dan Batuan.

Keterangan :

$$
\mathrm{NPPG}=\mathrm{NJ} \times \mathrm{Tp}
$$

NPPG $=$ Nilai Potensi Pajak Mineral Bukan Logam dan Batuan

$\mathrm{NJ} \quad=$ Nilai Produksi mineral bukan logam dan batuan

$\mathrm{Tp} \quad=$ Tarif Pajak $(\%)$

f. Pajak Penerangan Jalan

Perhitungan potensi pajak penerangan jalan menggunakan rumus menurut (Jamli dan Rahayu dalam Komalig 2014).

Keterangan :

$$
\begin{gathered}
\text { PPJ }=(J P \times J T \times J B) \times T p \\
\text { NPPPJ }=\text { PPJ } \times \text { Tp }
\end{gathered}
$$

PPJ = Pendapatan Penerangan Jalan (Rupiah)

NPPPJ = Nilai Potensi Pajak Penerangan Jalan (Rupiah)

$\mathrm{JP} \quad=$ Jumlah Pelanggan (Orang)

$\mathrm{JT}=$ Jumlah Tagihan (Rupiah/Orang/Bulan)

$\mathrm{JB}=$ Jumlah Bulan (bulan) $\mathrm{Tp}=$ Tarif Pajak (\%)

g. Pajak Sarang Burung Walet

Perhitungan potensi pajak sarang burung walet menggunakan rumus menurut (Jamli dan Rahayu dalam Komalig 2014).

Keterangan :

$$
\begin{gathered}
\mathrm{PSW}=\mathrm{JSW} \times \mathrm{JsPH} \times \mathrm{HSW} \\
\text { NPPSW }=\text { PSW } \times \mathrm{Tp}
\end{gathered}
$$

PSW = Pendapatan Sarang Burung Walet (Rupiah)

NPPSW = Nilai Potensi Pajak Sarang Burung Walet (Rupiah)

HSW $\quad=$ Harga Sarang Burung Walet (Rupiah/Kg)

JSW =Jumlah Sarang Burung Walet (Unit)

$\mathrm{Tp} \quad=$ Tarif Pajak $(\%)$

JsPH =Jumlah Pengambilan Sarang per hari (Kg/Unit)

\section{Menghitung Proyeksi Pajak Daerah}

$$
\operatorname{Pr}(\mathrm{t})=
$$

Keterangan :

$\operatorname{Pr}(\mathrm{t}) \quad=$ Proyeksi penerimaan pajak daerah pada tahun bersangkutan

$\mathrm{N}(\mathrm{t}-1)$ = Penerimaan atau realisasi pajak daerah satu tahun sebelumnya 


\section{ANALISIS DAN PEMBAHASAN \\ Gambaran Umum Objek Penelitian}

Kota Bitung merupakan salah satu dari lima belas Kabupaten/Kota yang ada di Provinsi Sulawesi Utara. Secara geografis Kota Bitung terletak pada posisi 1²3'23" - 1³5'39" Lintang Utara, dan $125^{\circ} 1^{\prime} 43^{\prime \prime}$ - $125^{\circ} 18^{\prime} 13^{\prime \prime}$ Bujur Timur. Wilayah daratan Kota Bitung mempunyai luas 31.350,35 ha, sedangkan luas wilayah perairan 43.980 ha, yang terbagi dalam 8 (delapan) wilayah Kecamatan serta 69 Kelurahan, yaitu sebagai berikut :

1. Kecamatan Madidir, yang memiliki 8 Kelurahan.

2. Kecamatan Matuari, yang memiliki 8 Kelurahan.

3. Kecamatan Girian, yang memiliki 7 Kelurahan.

4. Kecamatan Lembeh Selatan, yang memiliki 7 Kelurahan.

5. Kecamatan Lembeh Utara, yang memiliki 10 Kelurahan.

6. Kecamatan Aertembaga, yang memiliki 10 Kelurahan.

7. Kecamatan Maesa, yang memiliki 8 Kelurahan.

8. Kecamatan Ranowulu, yang memiliki 11 Kelurahan.

Berdasarkan data jumlah Penduduk Kota Bitung yaitu berjumlah 214.932 jiwa. Dan setiap tahun rata-rata pertumbuhan penduduk mencapai tiga persen, dan jika di hubungkan dengan luas wilayah Kota Bitung yang 31.350,35 ha atau $313 \mathrm{~km} 2$ maka kepadatan penduduk mencapai 686,7 jiwa per km2. Dilihat dari sebaran penduduk per Kecamatan, sebagian besar penduduk Bitung terkonsentrasi di Kecamatan Maesa, dimana 19,97 persen penduduk Bitung tinggal di kecamatan ini, selebihnya tersebar bervariasi di setiap kecamatan. Kecamatan Madidir 18,66 persen, Kecamatan Girian 14,48 persen, Kecamatan Aertembaga 14,71 persen, Kecamatan Matuari 13,05 persen, Kecamatan Ranowulu 8,75 persen, Kecamatan Lembeh Selatan 5,72 persen dan paling sedikit yaitu di Kecamatan Lembeh Utara yang hanya 4,67 persen.

\section{Hasil Penelitian}

Kota Bitung memiliki potensi - potensi yang bersumber dari perikanan, industri, perdagangan dan pariwisata. Pertumbuhan ekonomi merupakan sasaran utama yang ingin dicapai oleh pemerintah daerah Kota Bitung. Sejalan dengan meningkatnya dana untuk pembangunan, maka pemerintah daerah Kota Bitung terus berupaya dalam menggali potensi potensi yang ada untuk meningkatkan Pendapatan Asli Daerah (PAD). Penerimaan daerah yang bersumber dari Pendapatan Asli Daerah (PAD) memberikan kontribusi yang baik dalam peningkatan pendapatan daerah.

\section{Tabel 1}

Target dan Realisasi Penerimaan Pajak Daerah Kota Bitung Tahun 2011-2015

\begin{tabular}{ccccc}
\hline No & Tahun & $\begin{array}{c}\text { Target } \\
\text { (Rupiah) }\end{array}$ & $\begin{array}{c}\text { Realisasi } \\
\text { (Rupiah) }\end{array}$ & $\begin{array}{c}\text { Presentase } \\
(\%)\end{array}$ \\
\hline 1 & 2011 & 11.277 .205 .000 & 15.419 .397 .097 & 136,73 \\
2 & 2012 & 14.460 .500 .000 & 17.723 .643 .955 & 122,57 \\
3 & 2013 & 16.888 .970 .257 & 26.162 .693 .540 & 154,91 \\
4 & 2014 & 29.370 .000 .000 & 33.493 .759 .019 & 114,04 \\
5 & 2015 & 31.500 .000 .000 & 37.360 .100 .376 & 118,60 \\
\hline
\end{tabular}

Sumber : Dinas Pendapatan Daerah Kota Bitung, Data Olahan (2016) 
Tabel 2

Target dan Realisasi Pendapatan Asli Daerah (PAD) Kota Bitung

\begin{tabular}{ccccc}
\hline No & $\begin{array}{c}\text { Tahun } \\
\text { Anggaran }\end{array}$ & $\begin{array}{c}\text { Target } \\
\text { (Rupiah) }\end{array}$ & $\begin{array}{c}\text { Realisasi } \\
\text { (Rupiah) }\end{array}$ & $\begin{array}{c}\text { Prosentase } \\
(\%)\end{array}$ \\
\hline 1 & 2011 & 23.225 .000 .000 & 25.394 .063 .796 & 109,34 \\
2 & 2012 & 30.453 .039 .269 & 38.435 .120 .911 & 126,22 \\
3 & 2013 & 44.000 .000 .000 & 55.173 .113 .990 & 125,40 \\
4 & 2014 & 71.654 .094 .447 & 83.520 .151 .103 & 116,56 \\
5 & 2015 & 75.000 .000 .000 & 106.133 .530 .064 & 141,51 \\
\hline
\end{tabular}

Sumber : Dinas Pendapatan Daerah Kota Bitung, Data Olahan (2016)

Tabel 3

Realisasi Pajak Daerah Kota Bitung Tahun 2011 - 2015

\begin{tabular}{|c|c|c|c|c|c|}
\hline $\begin{array}{l}\text { Jenis } \\
\text { Pajak }\end{array}$ & 2011 & 2012 & 2013 & 2014 & 2015 \\
\hline Pajak Daerah & 15.419.397.097 & 17.723.643.955 & 26.162.693.540 & 33.493 .759 .019 & 37.360.100.376 \\
\hline Pajak Hotel & 1.375 .080 .887 & 1.457 .025 .208 & 1.800 .124 .842 & 2.079 .360 .152 & 1.695 .607 .242 \\
\hline Pajak Restoran & 1.200 .635 .664 & 1.805 .123 .000 & 2.307 .701 .798 & 2.584 .314 .625 & 2.606 .105 .374 \\
\hline Pajak Hiburan & 91.473 .739 & 198.637 .081 & 350.017 .975 & 345.389 .741 & 286.354 .760 \\
\hline Pajak Reklame & 627.220 .101 & 756.234 .975 & 809.534 .178 & 838.162 .296 & 836.869 .454 \\
\hline $\begin{array}{l}\text { Pajak } \\
\text { Penerangan }\end{array}$ & 6.226 .738 .438 & 8.089 .693 .620 & 9.879 .134 .934 & 12.776 .439 .417 & 12.829 .757 .492 \\
\hline $\begin{array}{l}\text { Jalan } \\
\text { Pajak Mineral } \\
\text { Bukan Logam } \\
\text { dan Batuan }\end{array}$ & 197.871 .682 & 556.225 .775 & 640.789 .991 & 317.167 .164 & 671.637 .571 \\
\hline Pajak Parkir & - & - & - & 2.610 .000 & 22.932 .900 \\
\hline $\begin{array}{l}\text { Pajak Air } \\
\text { Tanah }\end{array}$ & 291.096 .589 & 639.219 .514 & 789.506 .559 & 907.651 .894 & 1.315 .038 .395 \\
\hline $\begin{array}{l}\text { Pajak Sarang } \\
\text { Burung Walet }\end{array}$ & - & - & - & 5.300 .000 & 4.100 .000 \\
\hline $\begin{array}{l}\text { Pajak Bumi \& } \\
\text { Bangunan } \\
\text { Perdesaan \& } \\
\text { Perkotaan }\end{array}$ & - & - & - & 9.537 .670 .447 & 10.837 .187 .754 \\
\hline $\begin{array}{l}\text { Bea Perolehan } \\
\text { Hak atas } \\
\text { Tanah \& } \\
\text { Bangunan }\end{array}$ & 5.409 .279 .997 & 4.221 .484 .782 & 9.585 .883 .263 & 4.099 .693 .283 & 6.254 .509 .434 \\
\hline
\end{tabular}

Sumber : Dinas Pendapatan Daerah Kota Bitung, Data Olahan (2016) 
Analisis Data dan Pembahasan

Analisis Matriks Pertumbuhan dan Kontribusi.

Tabel 4

Pertumbuhan Kenaikan Pajak Daerah Kota Bitung Tahun 2011 - 2015

\begin{tabular}{cllc}
\hline Tahun & \multicolumn{1}{c}{$\begin{array}{c}\text { Realisasi } \\
\text { Pajak Daerah }\end{array}$} & Growth/ Pertumbuhan & $\begin{array}{c}\text { Prosentase } \\
(\boldsymbol{\%})\end{array}$ \\
\hline 2011 & Rp. 15.419.397.097,- & \multicolumn{1}{c}{. } & $\begin{array}{c}\text { 15\% } \\
2012\end{array}$ \\
2013 & Rp. 17.723.643.955,- & Rp. 2.304.246.858,- & $47 \%$ \\
2014 & Rp. 26.162.693.540,- & Rp. 8.439.049.585,- & $28 \%$ \\
2015 & Rp. 33.493.759.019,- & Rp. 7.331.065.479,- & $11 \%$ \\
\hline
\end{tabular}

Sumber : Data Olahan (2016)

Berdasarkan tabel 5.10 menunjukkan bahwa setiap tahun dari 2011 sampai dengan 2015 realisasi penerimaan pajak daerah mengalami peningkatan yaitu 14 persen pada tahun 2012, kemudian mengalami kenaikan 47 persen pada tahun 2013, tahun 2014 mengalami penurunan 28 persen, sedangkan pada tahun 2015 mengalami penurunan 11 persen. Hal ini harus terus diperhatikan baik dari pemungutan pajak yang berlaku maupun target yang di tetapkan.

\section{Analisis Potensi Pajak Daerah}

a. Pajak Hotel

Tabel 5

Perhitungan Potensi Pajak Hotel Kota Bitung

\begin{tabular}{lcccccc}
\hline $\begin{array}{l}\text { Klasifikasi } \\
\text { Hotel }\end{array}$ & $\begin{array}{c}\text { Jumlah } \\
\text { Kamar }\end{array}$ & $\begin{array}{c}\text { Tarif } \\
\text { Rata- } \\
\text { rata (Rp) }\end{array}$ & $\begin{array}{c}\text { Jumlah } \\
\text { Hari/Bulan }\end{array}$ & $\begin{array}{c}\text { Tingkat } \\
\text { Hunian } \\
\text { Kamar }\end{array}$ & $\begin{array}{c}\text { Tarif } \\
\text { Pajak }\end{array}$ & $\begin{array}{c}\text { Potensi } \\
\text { Pajak (Rp) }\end{array}$ \\
\hline $\begin{array}{l}\text { Hotel } \\
\text { Berbintang }\end{array}$ & 113 & 550.000 & 365 & 0,70 & $10 \%$ & 1.587 .932 .500 \\
\hline Melati & 332 & 350.000 & 365 & 0,45 & $10 \%$ & 1.908 .585 .000 \\
\hline Cottage & 84 & 1.850 .000 & 365 & 0,80 & $10 \%$ & 4.537 .680 .000 \\
\hline $\begin{array}{l}\text { Rumah } \\
\text { Kost }\end{array}$ & 490 & 400.000 & 12 & 0,89 & $10 \%$ & 209.328 .000 \\
\hline Total & & & & & & \\
\hline Sumber: Data Olahan (2016) & & & & & &
\end{tabular}

b. Pajak Restoran

Tabel 6

Perhitungan Potensi Pajak Restoran Kota Bitung

\begin{tabular}{lcccccc}
\hline $\begin{array}{l}\text { Klasifikasi } \\
\text { Restoran }\end{array}$ & $\begin{array}{c}\text { Jumlah } \\
\text { Restoran }\end{array}$ & $\begin{array}{c}\text { Estimasi } \\
\text { Pengunjung } \\
\text { Rata-rata } \\
\text { Perhari }\end{array}$ & $\begin{array}{c}\text { Tarif } \\
\text { Rata- } \\
\text { rata (Rp) }\end{array}$ & $\begin{array}{c}\text { Jumlah } \\
\text { Hari }\end{array}$ & $\begin{array}{c}\text { Tarif } \\
\text { Pajak }\end{array}$ & $\begin{array}{c}\text { Potensi } \\
\text { Pajak (Rp) }\end{array}$ \\
\hline $\begin{array}{l}\text { Restoran } \\
\text { Besar }\end{array}$ & 5 & 45 & 35.000 & 365 & $10 \%$ & 287.437 .500 \\
Restoran & 23 & 163 & 25.000 & 365 & $10 \%$ & 3.420 .962 .500
\end{tabular}


Sedang

Restoran

153

224

15.000

365

$10 \%$

18.763.920.000

Kecil

181

22.472.320.000

Sumber: Data Olahan (2016)

c. Pajak Hiburan

Tabel 7

Perhitungan Potensi Pajak Hiburan Kota Bitung

\begin{tabular}{cccccc}
\hline $\begin{array}{c}\text { Jumlah } \\
\text { Hiburan }\end{array}$ & $\begin{array}{c}\text { Rata-rata } \\
\text { tamu yang } \\
\text { datang }\end{array}$ & $\begin{array}{c}\text { Rata-rata } \\
\text { pembayaran } \\
\text { per tamu }\end{array}$ & $\begin{array}{c}\text { Jumlah } \\
\text { Bulan }\end{array}$ & $\begin{array}{c}\text { Tarif } \\
\text { Pajak }\end{array}$ & $\begin{array}{c}\text { Potensi } \\
\text { Pajak }\end{array}$ \\
\hline 53 & 150 & 35.000 & 12 & $20 \%$ & 667.800 .000 \\
\hline Total & & & & & $\mathbf{6 6 7 . 8 0 0 . 0 0 0}$ \\
\hline
\end{tabular}

Sumber: Data Olahan (2016)

d. Pajak Reklame

Tabel 8

Perhitungan Potensi Pajak Reklame Kota Bitung

\begin{tabular}{lccccc}
\hline Klasifikasi Reklame & $\begin{array}{c}\text { Jumlah } \\
\text { Reklame }\end{array}$ & $\begin{array}{c}\text { Tarif } \\
\text { Rata-rata } \\
(\mathbf{R p})\end{array}$ & $\begin{array}{c}\text { Jumlah } \\
\text { per } \\
\text { triwulan / } \\
\text { Tahun }\end{array}$ & $\begin{array}{c}\text { Tarif } \\
\text { Pajak }\end{array}$ & $\begin{array}{c}\text { Potensi Pajak } \\
\text { (Rp) }\end{array}$ \\
\hline $\begin{array}{l}\text { Papan, Baliho \& } \\
\text { Billboard }\end{array}$ & 497 & 800.000 & 4 & $25 \%$ & 397.600 .000 \\
\hline Kain/Spanduk & 568 & 500.000 & 4 & $25 \%$ & 340.800 .000 \\
\hline Melekat/Stiker, Berjalan & 281 & 350.454 & 4 & $25 \%$ & 98.477 .574 \\
\hline \multicolumn{1}{c}{ Total } & $\mathbf{1 3 4 6}$ & & & & $\mathbf{8 3 6 . 8 7 7 . 5 7 4}$ \\
\hline
\end{tabular}

Sumber: Data Olahan (2016)

e. Pajak Penerangan Jalan

Tabel 9

Perhitungan Potensi Pajak Penerangan Jalan Kota Bitung

\begin{tabular}{ccccc}
\hline $\begin{array}{c}\text { Jumlah } \\
\text { Pelanggan }\end{array}$ & $\begin{array}{c}\text { Jumlah } \\
\text { Tagihan (Rp) }\end{array}$ & Jumlah Bulan & Tarif Pajak & $\begin{array}{c}\text { Potensi Pajak } \\
\text { (Rp) }\end{array}$ \\
\hline 38.226 & 350.000 & 12 & $10 \%$ & 16.054 .920 .000 \\
\hline Total & & & & $\mathbf{1 6 . 0 5 4 . 9 2 0 . 0 0 0}$ \\
\hline
\end{tabular}

Sumber: Data Olahan (2016)

f. Pajak Mineral Bukan Logam dan Batuan

Tabel 10

Perhitungan Potensi Pajak Mineral Bukan Logam dan Batuan Kota Bitung

\begin{tabular}{cccc}
\hline Nilai Produksi & Jumlah Bulan & Tarif Pajak (Rp) & Potensi Pajak (Rp) \\
\hline 671.637.571 & 12 & $25 \%$ & 2.014 .912 .713 \\
Total & & & $\mathbf{2 . 0 1 4 . 9 1 2 . 7 1 3}$ \\
\hline
\end{tabular}

Sumber: Data Olahan (2016) 


\section{g. Pajak Parkir}

Tabel 11

Perhitungan Potensi Pajak Parkir Kota Bitung

\begin{tabular}{ccccccc}
\hline $\begin{array}{c}\text { Tempat } \\
\text { Lahan } \\
\text { Parkir }\end{array}$ & $\begin{array}{c}\text { Rata-rata } \\
\text { Kendaraan Parkir } \\
\text { Perbulan }\end{array}$ & $\begin{array}{c}\text { Jumlah } \\
\text { Bulan }\end{array}$ & & $\begin{array}{c}\text { Jumlah } \\
\text { Tagihan }\end{array}$ & $\begin{array}{c}\text { Tarif } \\
\text { Pajak }\end{array}$ & $\begin{array}{c}\text { Potensi } \\
\text { Pajak } \\
\text { (Rp) }\end{array}$ \\
\cline { 2 - 6 } & Mobil & Motor & & & & \\
\hline Rs.Budi Mulia & 120 & 250 & 12 & 2.000 & $30 \%$ & 2.664 .000 \\
\hline Citymart 1 & 300 & 800 & 12 & 2.000 & $30 \%$ & 7.920 .000 \\
\hline Citymart 2 & 200 & 360 & 12 & 2.000 & $30 \%$ & 4.032 .000 \\
\hline $\begin{array}{c}\text { Rs.Manembo- } \\
\text { nembo }\end{array}$ & 150 & 200 & 12 & 2.000 & $30 \%$ & 2.520 .000 \\
\hline Rs.Angkatan Laut & 70 & 100 & 12 & 2.000 & $30 \%$ & 1.224 .000 \\
\hline Total & & & & & $\mathbf{1 8 . 3 6 0 . 0 0 0}$ \\
\hline
\end{tabular}

Sumber: Data Olahan (2016)

\section{h. Pajak Air Tanah}

Berdasarkan observasi dilapangan dengan data dari Dinas Pendapatan Daerah Kota Bitung target Pajak Air Tanah tahun 2015 sebesar Rp.900.000.000,- dengan realisasi sebesar Rp.1.315.038.395,- Objek Pajak yang terdata di Dinas Pendapatana Daerah hanya sebesar 94 objek pajak sedangkan yang belum terdata masih banyak. Kemudian jumlah pemakaian air tanah yang di laporkan wajib pajak masih ada sebagian yang jumlahnya yang belum sesuai dengan yang sebenarnya karena banyak wajib pajak yang tidak menggunakan meteran. Sehingga mengalami kendala dalam penetapan Pajak terutang, hal ini menjadi potensi yang bisa di garap oleh Pemerintah Daerah Kota Bitung dalam meningkatkan penerimaan Pajak Air Tanah sehingga dapat meningkatkan Pendapatan Daerah Kota Bitung.

\section{i. Pajak Bumi dan Bangunan Perdesaan dan Perkotaan}

Pajak PBB-P2 baru mulai dipungut atau dikelola oleh Dinas Pendapatan Daerah Kota Bitung tahun 2014. Realisasi Pajak PBB-P2 tahun 2015 sebesar Rp. 10.837.187.754 melebihi target yang telah ditetapkan oleh Dinas Pendapatan Daerah Kota Bitung sebesar Rp. 9.000.000.000. meningkat dari tahun 2014 realisasinya sebesar Rp 9.537.670.447. Pada tahun 2015 terdapat 455 Permohonan PBB-P2. NJOP yang ditetapkan oleh Dinas Pendapatan Daerah Kota Bitung masih jauh dari nilai pasaran terutama jalan - jalan utama hal ini menjadi perhatian bagi Pemerintah Daerah untuk menaikkan standar nilai pasaran mengingat potensi Kota Bitung cukup besar disebabkan adanya kegiatan pembangunan yang dilakukan oleh pemerintah yang berdampak pada perkembangan wilayah dan perkembangan ekonomi daerah. 


\section{j. Pajak Sarang Burung Walet}

Tabel 11

Perhitungan Potensi Pajak Sarang Burung Walet Kota Bitung

\begin{tabular}{ccccc}
\hline $\begin{array}{c}\text { Jumlah Sarang } \\
\text { Burung Walet }\end{array}$ & $\begin{array}{c}\text { Jumlah } \\
\text { Penghasilan Per } \\
\text { tahun }(\mathbf{K g})\end{array}$ & $\begin{array}{c}\text { Harga Sarang } \\
\text { Burung Walet } \\
\text { /Kg (Rp) }\end{array}$ & Tarif Pajak & $\begin{array}{c}\text { Potensi Pajak } \\
(\mathbf{R p})\end{array}$ \\
\hline 9 & 7 & 4.000 .000 & $5 \%$ & $\begin{array}{c}12.600 .000 \\
\text { Total }\end{array}$ \\
\hline
\end{tabular}

Sumber: Data Olahan (2016)

Menghitung Proyeksi Penerimaan Potensi Pajak Daerah 5 tahun ke depan

Tabel 12

Potensi Penerimaan Pajak Daerah

\begin{tabular}{|c|c|c|c|}
\hline Tahun & Paiak Darah & Pertumbuhan & $(\%)$ \\
\hline Ialmum & rajak уaeran & rertumbunan & \\
\hline 2011 & Rp. 15.419.397.097,- & - & - \\
\hline 2012 & Rp. 17.723.643.955,- & Rp. 2.304.246.858,- & $14 \%$ \\
\hline 2013 & Rp. 26.162.693.540,- & Rp. 8.439.049.585,- & $47 \%$ \\
\hline 2014 & Rp. 33.493.759.019,- & Rp. 7.331.065.479,- & $28 \%$ \\
\hline 2015 & Rp. 37.360.100.376,- & Rp. 3.866.341.357,- & $11 \%$ \\
\hline 2016 & Rp. 46.700.125.470,- & Rp. 9.340.025.094,- & $25 \%$ \\
\hline 2017 & Rp. 58.375.156.837,- & Rp. 11.675.031.367,- & $25 \%$ \\
\hline 2018 & Rp. 72.968.946.046,- & Rp. 14.593.789.209,- & $25 \%$ \\
\hline 2019 & Rp. 91.211.182.557,- & Rp. 18.242.236.511,- & $25 \%$ \\
\hline 2020 & Rp. 114.013.978.196,- & Rp. 22.802.795.639,- & $25 \%$ \\
\hline
\end{tabular}

Sumber: Data Olahan (2016)

Dari tabel 5.23 menunjukkan bahwa potensi penerimaan Pajak Daerah di Kota Bitung untuk 5 tahun mendatang dapat diproyeksikan. Dari perhitungan rata-rata tingkat pertumbuhan tahun 2011 sampai dengan 2015 terjadi kenaikan 25 persen sehingga hasil Pajak Daerah tahun 2016 sampai dengan 2020 yaitu pada tahun 2016 Rp.46.700.125.470,- tahun 2017 Rp.58.375.156.837,- tahun 2018 Rp.72.968.946.046,- tahun 2019 Rp.91.211.182.557,- dan tahun 2020 Rp.114.013.978.196.-

\section{Kesimpulan}

\section{KESIMPULAN DAN SARAN}

Berdasarkan hasil penelitian dan pembahasan pada bab sebelumnya, maka dapat diambil kesimpulan bahwa:

1. Penerimaan Pajak Daerah Kota Bitung tahun 2011 - 2015 mengalami peningkatan dengan realisasi yang diperoleh mampu mencapai bahkan melebihi target yang telah di tetapkan. Namum presentase kontribusi pajak daerah terhadap Pendapatan Asli Daerah (PAD) mengalami fluktuasi dari tahun ke tahun.

2. Penerimaan pajak daerah Kota Bitung dalam kurun waktu lima tahun dari tahun 2011 sampai dengan 2015 yaitu pada tahun 2011 Rp. 15.419.397.097, tahun 2012 Rp. 17.723.643.955, 
tahun 2013 Rp. 26.162.693.540, tahun 2014 Rp. 33.493.759.019, dan pada tahun 2015 Rp. 37.360.100.376. Pertumbuhan dan Kontribusi dari setiap jenis pajak daerah dari tahun ke tahun sangat bervariasi, jenis pajak yang memberikan kontribusi terbesar terhadap pajak daerah yaitu pajak penerangan jalan sebesar 39,26 persen, jenis pajak yang mengalami pertumbuhan terbesar yaitu pajak parkir sebesar 194,66 persen.

3. Berdasarkan hasil survei potensi terhadap pajak daerah, Kota Bitung memiliki potensi yang belum digali oleh pemerintah dalam hal ini DISPENDA yang memiliki potensi untuk dikembangkan yaitu pajak restoran dan pajak hotel maka perhitungan yang dilakukan terhadap potensi sebenarnya diketahui bahwa pajak daerah memiliki potensi yang besar, karena target yang ditetapkan pemerintah masih di bawah potensi yang sesuai dengan kondisi yang sebenarnya yang ada di Kota Bitung

4. Klasifikasi potensi pajak sesuai dengan hasil analisis, jika termasuk dalam kategori prima, maka harus dipertahankan, jika termasuk dalam kategori potensial yang dilakukan adalah mengintensifkan yang sudah ada biar tercapai pertumbuhan, tetapi jika termasuk penerimaan berkembang, maka harus dilakukan langkah ekstensifikasi, dan yang tergolong terbelakang, maka justru perlu adanya evaluasi, apakah sumber penerimaan yang menguntungkan atau jenis akan merugikan.

5. Proyeksi potensi penerimaan pajak daerah Kota Bitung pada tahun 2016 sampai dengan 2020 akan terjadi kenaikan sebesar 25 persen.

\section{Saran}

Berdasarkan hasil penelitian dan pembahasan pada bab sebelumnya, maka dapat diberikan saran antara lain sebagai berikut:

1. Pertumbuhan dan kontribusi pajak daerah mengalami fluktuasi di Kota Bitung, maka perlu dilakukan intensifikasi dan ekstensifikasi pendapatan dari setiap jenis pajak daerah agar mengalami peningkatan yaitu dengan melakukan perhitungan potensi setiap jenis pajak daerah, karena berdasarkan pengamatan di lapangan penetapan target pendapatan setiap jenis pajak daerah masih dilakukan secara incremental sehingga belum mengambarkan potensi yang sebenarnya.

2. Klasifikasi potensi pajak sesuai dengan hasil analisis dapat diketahui pertumbuhan dan kontribusi jenis pajak daerah di Kota Bitung terdapat empat jenis pajak yang teridentifikasi terbelakang yaitu pajak hotel, pajak restoran, reklame dan pajak sarang burung walet. Hal ini perlu dilakukan peningkatan pertumbuhan dan kontribusi seiring dengan peningkatan total pendapatan masing-masing jenis pajak daerah.

3. Pengelolaan sumber pendapatan daerah seperti Pajak Daerah perlu diidentifikasi karena banyak sumber-sumber pendapatan yang belum dikelola secara tepat, serta pengawasan yang belum efektif oleh pemerintah sehingga dalam pemungutan pajak belum maksimal.

4. Kontrol Pemerintah terhadap instansi terkait lebih ditingkatkan lagi agar tercipta kinerja yang baik sehingga tahun-tahun selanjutnya dapat memberikan hasil yang memuaskan dari penerimaan pajak daerah dengan melakukan sosialisasi yang lebih intensif lagi kepada Wajib pajak khususnya dan masyarakat pada umumnya untuk membangun kesadaran dalam membayar pajak. Dan memberikan sanksi tegas kepada wajib pajak yang tidak memenuhi kewajiban perpajakan sebagaimana mestinya.

5. Pemerintah Kota Bitung perlu meningkatkan infrastuktur dan sarana prasarana untuk menunjang pertumbuhan pendapatan daerah dan perlu adanya kegiatan-kegiatan yang dilakukan pemerintah setempat, seperti pengenalan objek wisata, pameran-pameran budaya, membuat tempat kuliner, perkembangan kegiatan - kegiatan ekonomi sehingga 
mempengaruhi pertumbuhan pajak sehingga bisa meningkatkan PAD khususnya sektor pajak daerah

\section{DAFTAR PUSTAKA}

Mangkoesoebroto, Guritno. 2001. Ekonomi Publik, Yogyakarta: BPFE.

Sumual, R, Juliana. 2016. Pengaruh Realisasi Belanja Daerah dan Angkatan Kerja Terhadap Perkembangan PDRB Provinsi Sulawesi Utara Tahun 2004 - 2013.Universitas Sam Ratulangi Manado. Vol 16 No 01.

Undang - Undang Nomor 28 Tahun 2009 tentang Pajak Daerah dan Retribusi Daerah.

Sumarsan, Thomas. 2013. Perpajakan Indonesia.: Pedoman Perpajakan Indonesia Lengkap Berdasarkan Undang - Undang Terbaru. Jakarta.

Laksmana, A Putratama. 2016. Kemampuan Keuangan Daerah Kota Bitung dari Sektor Pajak Daerah. Program Pascasarjana Universitas Terbuka Jakarta.

Muklis, Imam. 2010. Peran Pajak Daerah dalam Meningkatkan Pendapatan Asli Daerah. Disertasi. Universitas Negeri Malang.

Mardiasmo. 2009. Akuntansi Sektor Publik. Penerbit ANDI Yogyakarta.

Mardiasmo. 2013. Perpajakan Edisi Revisi. Penerbit ANDI Yogyakarta.

Alfirman, Luky. 2003. Estimating Stochastic Frontier Tax Potential: Can Indonesian Local Governments Increase Tax Revenues Under Decentralization. University of Colorado at Boulder Boulder, Colorado. Hal 03 -19.

Mahsun, Mohamad. 2009. Pengukuran Kinerja Sektor Publik. Edisi Kedua. Penerbit ANDI Yogyakarta. Fakultas Ekonomi UGM.

Komalig, Norma. 2014. Potensi Peningkatan Pendapatan Asli Daerah di Kabupaten Minahasa Tenggara. Jurnal Tesis. Universitas Sam Ratulangi Manado. 